\title{
Chemical defence in ladybird beetles (Coccinellidae). I. Distribution of coccinelline and individual variation in defence in 7-spot ladybirds (Coccinella septempunctata)
}

\author{
Graham J. Holloway, Peter W. de Jong, Paul M. Brakefield, and Helene de Vos \\ Section of Evolutionary Biology, Department of Population Biology, University of Leiden, Schelpenkade 14a, \\ NL-2313 ZT Leiden, The Netherlands
}

Received November 20, 1990 / Revision accepted February 21, 1991

\section{Summary}

7-spot ladybirds secrete alkaloid (coccinelline)-rich fluid (reflex blood) from leg joints as a defence mechanism against predators. A technique is described that enables the collection and accurate quantification of reflex blood produced, and the amount of coccinelline therein. Coccinelline was found distributed throughout the body, although concentrated in the reflex blood. Reflex blood was collected from a large set of beetles at several time points. Significant variation was found among beetles in the amount of reflex blood produced (for males and for females cor- rected for body weight) and the coccinelline concentration of the reflex blood. The results are discussed in relation to automimicry and the maintenance of variation through energy trade-offs. The relationships between tendency to aggregate, ability to reflex bleed and the possession of aposematic coloration are also considered.

\section{Key words}

chemical defence, mimicry, reflex bleeding, variation, alkaloid, coccinelline, Coleoptera, Coccinellidae, Coccinella septempunctata

\section{Introduction}

Mimicry provides one of the most obvious and clear-cut examples of a consequence of natural selection (Fisher 1930). Mimetic systems have been studied at a number of different levels, including the genetics and evolution of aposematic (warning) coloration (Turner 1977, 1984; Sheppard et al. 1985) and the factors causing distastefulness (e.g. Brower et al. 1967; Brower 1984; Rothschild 1985; Malcolm \& Brower 1989). Variation in chemical defence as a consequence of among individual differences in physiology, rather than variation in the host plant, has been less studied (but see de Jong et al. 1991), perhaps due to the difficulty commonly experienced in accurately quantifying toxic components.

The conditions required for the evolution of bright and obvious warning coloration are far from clear (see Guilford (1988) for consideration of problems), although once established, normalizing selection is expected to remove genetic variation and maintain a uniform colour pattern throughout the population (Turner 1984). Indeed, in single (panmictic) field populations of species, there is usually very little variation in warning coloration, at least for Müllerian mimics. This is true for the 7-spot ladybird beetle, Coccinella septempunctata L., although some variation within the aposematic colour scheme, e.g. variable spot size, is present (Dobzhansky \& Sivertzev-Dobzhansky 1927; Hodek 1973). Furthermore, ladybirds, including $C$. septempunctata, are considered to form mimetic assemblages (Brakefield 1985a).

(c) Georg Thieme Verlag Stuttgart · New York
Guilford (1988) argued that aposematic coloration was most likely to evolve in a species that was already distasteful. The 7-spot ladybird is distasteful and toxic to some bird predators (Marples et al. 1989) and the alkaloid, coccinelline (Tursch et al. 1971, 1975, 1976; Meuller et al. 1984), which is synthesised by the beetles themselves (Pasteels et al. 1973), is the major toxic component of their chemical defence (Marples 1990). Indeed, many ladybird species synthesise alkaloids internally as defensive substances (Pasteels et al. 1973; Ayer \& Browne 1977). Defence fluid is exuded by an active ladybird as soon as it is attacked by a predator; a behaviour called reflex bleeding (Cuenot 1896; Hollande 1911; Frazer \& Rothschild 1960; Happ \& Eisner 1961), although 7spot ladybird defence fluid does not contain the blood cells found in the haemolymph (Kay et al. 1969).

In well defended species, such as the 7-spot ladybird (Marples et al. 1989), the evolution of warning mechanisms is expected. This is achieved through bright aposematic coloration and the emission of volatile repellent compounds, such as pyrazines (Rothschild 1961; Guilford et al. 1987). The basic warning coloration, at least, is invariable within population. However, the possession of signals advertising toxicity and distastefulness may alter the selective influences on the production of defence fluid in ladybirds. Internal synthesis of defensive molecules may be metabolically more costly than sequestration, but the production of copious quantities of fluid to transport these chemicals must surely be energetically costly. As a result there may be selection to reduce the amount of energy allocated to defence and to relocate resources to other functions, for example oviposition (Williams 1966; Sibly \& Calow 1986; Smith et al. 1987; Holloway et al. 1990a, b). 
Thus, if all conspecifics are defended and warningly coloured, it may pay an individual to become a Batesian mimic of conspecific (or nonconspecific) models, i.e. automimicry (Brower et al. 1967, 1970; Pough 1973; Gibson 1974). Guilford (1988) acknowledged the possibility of this type of 'cheating' in recognizably well defended species, such as 7-spot ladybirds. The evolution of a mixed evolutionary stable strategy (ESS) (Maynard Smith 1982) that balances the cost of unpalatability against increased chance of predation becomes a possibility. The development of automimicry becomes still more likely in an aposematically colored species that aggregates. Here, if a naive predator discovers an aggregation, the chance of being sampled is clearly much less than if a single animal is found (providing the predator finds the defended prey distasteful). 7-spot ladybirds form such aggregations, particularly during winter hibernation (Hemptinne 1988; Majerus \& Kearns 1989) and summer aestivation (pers. obs.).

It seems plausible that although the aposematic coloration is invariable in 7-spot ladybirds, there may be substantial variation in the amount or toxicity of defence fluid produced. The purpose of the present study, therefore, was two fold:

1. to establish how the 7-spot ladybird defends itself, i.e. is the defensive alkaloid distributed throughout the body or is energy channelled into producing only the toxic secretion?

Whether ladybirds remain toxic during the winter months and are still able to reflex bleed may be influential in determining the need to aggregate in groups at certain times of the year. Furthermore, we also wished to test:

2. whether among beetle variation exists in the amount of fluid produced and the concentration of alkaloid therein and, if so, whether the findings are consistent with the existence of a mixed ESS suggesting the development of automimicry?

\section{Materials and Methods}

\section{Insects}

Adult 7-spot ladybirds were collected from ivy (Hedera helix) in Leiden (The Netherlands) as they emerged from winter hibernation in February, 1990. 210 unsexed insects were distributed at random across four groups. Three of the groups (A to C) contained 20 beetles whilst the fourth group (D) contained the remaining 150. Each ladybird was maintained separately in a $5 \mathrm{~cm}$ diameter plastic petridish and kept in a constant climate cabinet $\left(20^{\circ} \mathrm{C}, 80 \%\right.$ relative humidity, 18:6 light:dark). In addition, each animal in group D was sexed using ventral surface abdominal characteristics. The ladybirds were provided with a clean petri dish and fresh pea aphids (Acyrthosiphon pisum) every day derived from infested laboratory bean plants, so that an ample food supply was always available. After a period of time, many of the female ladybirds began to lay batches of eggs. The numbers of eggs laid were counted.

\section{Extraction and collection of reflex blood}

A length of flexible silicone rubber tubing (2.3 mm diameter) was attached to a tap-operated vacuum pump. The suction created by touching the tube down onto the elytra was sufficient to pick up an individual ladybird. This rarely induced reflex bleeding; the use of forceps or fingers almost always did. The beetle could then be held ventral side upwards and stimulated to produce reflex blood by touching the exposed thorax or legs with a $10 \mu \mathrm{l}$ capacity capillary tube. When a drop of fluid was produced (usually instantly) the capillary tube was turned through $180^{\circ}$ and the fluid taken up in the opposite end of the tube. The beetle could then be stimulated to produce more reflex blood by using the dry end of the capillary tube, which again was collected in the opposite end of the tube and so on until secretion ceased. Occasionally a second tube was required to complete collection.

The amount of the fluid produced was calculated by weighing the capillary tube before and after bleeding on a Metler AE 160 top pan balance (to $\pm 0.01 \mathrm{mg}$ ). The tube plus fluid was quickly transferred to an Eppendorf vial containing $0.2 \mathrm{ml}$ methanol. It was then shaken vigorously for a few seconds to disperse the solvent along the capillary tube. The capillary tubes were left overnight in the methanol in sealed Eppendorfs. A gentle stream of air was then used to blow any methanol from the tube into the Eppendorf. The solvent was allowed to evaporate off at room temperature.

All ladybirds were weighed after being reflex bled to the nearest $0.1 \mathrm{mg}$. Groups $\mathrm{A}, \mathrm{B}$ and $\mathrm{C}$ ladybirds were examined on days 1,3 and 5 , respectively, to determine the rate at which reflex blood could build up following hibernation and also to establish an appropriate length of time to leave the beetles in group D between bleedings. Group D ladybirds were used to examine variation among beetles. These ladybirds were bled and weighed on days 8,15 and 22 , so that for each beetle there were three values of fluid weight, body weight and amount of coccinelline. After the final bleeding and weighing on day 22 , all beetles were frozen at $-30^{\circ} \mathrm{C}$.

\section{Alkaloid analysis}

Following evaporation of the methanol, the Eppendorfs were kept at $4{ }^{\circ} \mathrm{C}$. The amount of alkaloid in each extract was measured using a Packard 433 Gas Chromatograph (GC). Prior to injection each extract was redissolved in (exactly) $0.2 \mathrm{ml}$ methanol. $0.2 \mu \mathrm{l}$ of each resulting solution was injected into the GC. Material was allowed to pass through the column ( $25 \mathrm{~m}$ long, $0.53 \mathrm{~mm}$ inner diameter CPSil 8) for $10 \mathrm{~min}$ at a temperature of $185^{\circ} \mathrm{C}$ using $\mathrm{H}_{2}(7.18$ $\mathrm{ml} / \mathrm{min}$ ) as carrier gas. The coccinelline appeared on the trace in less than $3 \mathrm{~min}$, but running for a longer period of time ensured that each subsequent sample was free from contamination by the last. No distinction was made between coccinelline and its free base, precoccinelline (Tursch et al. 1971, 1976).

\section{Distribution of defensive alkaloid in the body}

Ladybirds in groups A, B and C were also used to determine the distribution of defensive alkaloid through the body after reflex bleeding. 10 insects from each group were taken at random and dipped in chloroform for a few seconds to remove any alkaloid contaminating the surface of the animal following bleeding. Each beetle, dipped or otherwise, was then dissected into the legs, the wings (including the elytra), the head, the thorax and the abdomen. Each 
of the five components was weighed to $0.01 \mathrm{mg}$ before being dropped separately into Eppendorfs containing $0.2 \mathrm{ml}$ chloroform. Chloroform was used rather than methanol to ensure thorough penetration of each body component to remove all remaining alkaloid. After soaking in chloroform overnight the Eppendorf lids were opened to allow the solvent to evaporate before being stored at $4{ }^{\circ} \mathrm{C}$ prior to analysis. $0.2 \mathrm{ml}$ methanol was added to each Eppendorf to redissolve the coccinelline before GC injection and analysis as described above.

\section{Results}

The reflex fluid was only observed to exude from the joint between the femur and tibia. The beetles were able to produce fluid from all six legs, although it was sometimes difficult to see separate drops of fluid from the first and second legs since they are so close together that the droplets often combined. It was also possible to cause each leg to produce reflex fluid completely independently. Fluid often emerged only from the leg that was being directly stimulated. As the reflex fluid 'reserves' were becoming exhausted it usually turned from the opaque colour of the haemolymph (pale lemon yellow through to orange), as seen through the throat membrane, to being less coloured and more translucent. It also became more 'sticky'. The reflex fluid collected before this colour change generally did not congeal particularly quickly on contact with the air, although there was evidently some variation among beetles with respect to this quality.

The mean amounts of reflex blood produced by the beetles in the various groups are shown in Figure 1A. Well-fed ladybirds quickly accumulated reflex blood and production appeared to approach a maximum after a week. It was decided, therefore, to use a seven day interval between subsequent bleedings of beetles in group D. In the event, seven days was only sufficient to enable the beetles to reflex bleed from between $60 \%$ and $70 \%$ of full capacity (assuming that they could have regained the postwinter hibernation maximum).

The amount of coccinelline carried in the reflex blood is shown in Figure 1B. The change in coccinelline production was not as great as the increase in reflex blood production. Consequently, the concentration of the alkaloid in the reflex blood declined to a steady value between the 'bleedings' on days 15 and 22 (Fig. 1C). The observations suggest that substantial amounts of coccinelline are present in overwintering ladybirds despite their probable inability to reflex bleed.
The results of the analyses of the body components are shown in Table 1 . In order to standardize the results and to allow comparisons to be made, the results are presented as $\mu \mathrm{g}$ coccinelline per $\mathrm{mg}$ fresh weight of each body component and per mg fluid. Coccinelline was found to be present throughout the body. The amount of coccinelline de-

A

B

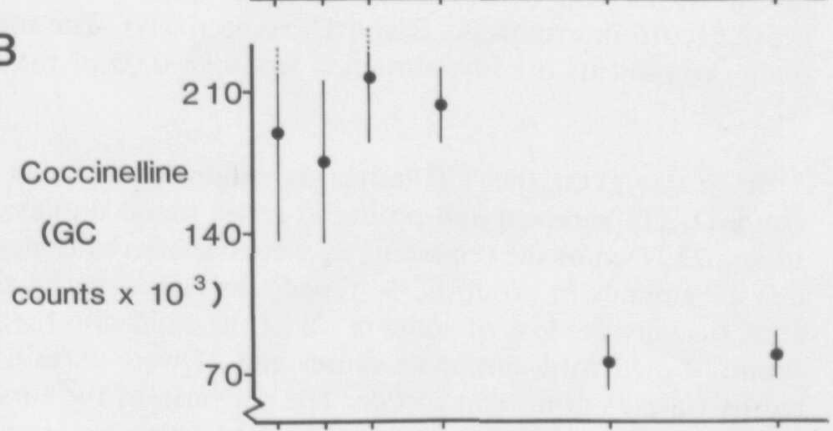

C

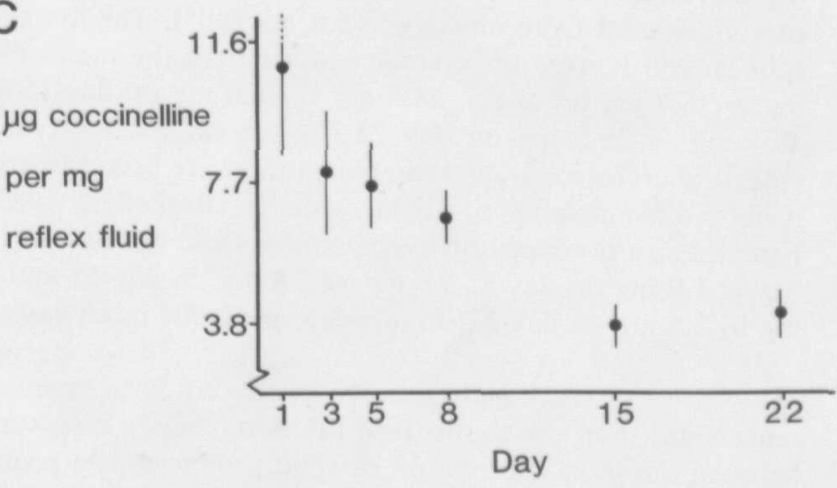

Fig. 1 Change through time in A amount $(\mathrm{mg})$ of fluid produced, B amount (GC counts) of coccinelline produced and $C$ coccinelline concentration $(\mu \mathrm{g} / \mathrm{mg})$ of the reflex blood. Mean values with $95 \%$ confidence intervals

Table $1 \mu \mathrm{g}$ coccinelline per $\mathrm{mg}$ body tissue and per $\mathrm{mg}$ reflex fluid from ladybirds undipped (U) or dipped (D) in chloroform prior to dissection after feeding on aphids for 1,3 or 5 days. All values derived from 10 observations

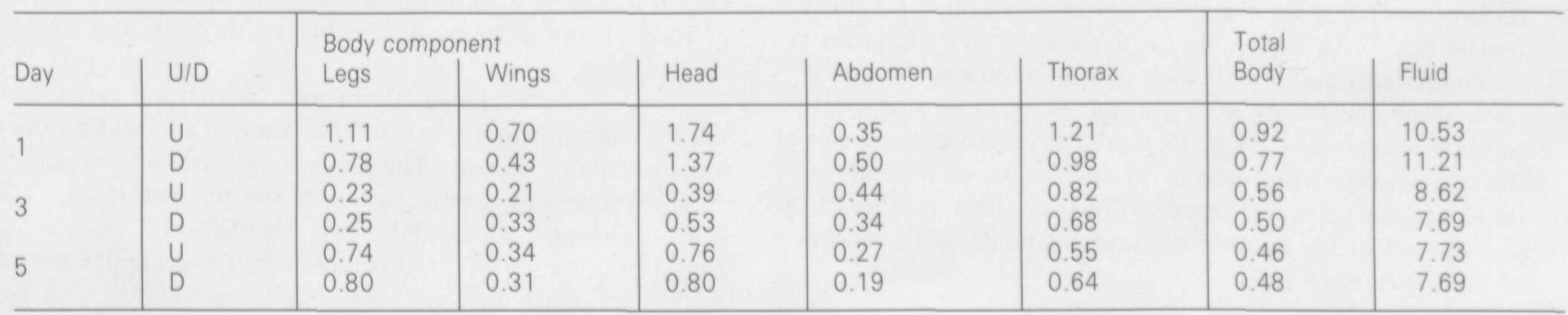

Least significant difference between any two means is 0.54 
tected by the GC that was removed by the chloroform during dipping was generally small. Dipping in chloroform prior to dissection had little effect on the amount of alkaloid detected, with the possible exception of the legs, wings and head of group A ladybirds (Table 1). Here the amount of alkaloid detected was lowered by dipping, though not to a significant extent. Overall, however, it was clear that most of the coccinelline was contained within the body (or reflex fluid) and not present as a surface contaminant. There was substantial variation about each mean alkaloid concentration for each component which may obscure any real differences between them. The concentration of the reflex blood, though, was around 10 times that of any of the body parts and, consequently, was significantly higher than all other values (in all cases $\mathrm{p}<0.001$ ). As a mean proportion ( \pm s.e.) of total alkaloid in each beetle, $0.517 \pm 0.046$ (group A), $0.607 \pm 0.04$ (group B) and $0.705 \pm 0.02$ (group $C$ ) of the coccinelline was carried within the reflex blood (values calculated from angular transformed data). Most of the remaining coccinelline was contained within the thorax $(0.294 \pm 0.031,0.259 \pm 0.029$ and $0.242 \pm 0.016$ in groups $\mathrm{A}, \mathrm{B}$ and $\mathrm{C}$, respectively). The other body components usually contained less than 0.05 of the total.

Of the 150 ladybirds originally assigned to group D, 111 survived and produced reflex blood on days 8, 15 and 22 . Two of the remaining 39 were transferred to maintain 20 animals in group C, 9 'failed' through experimental error (usually the loss of some or all of the fluid into the vacuum), 7 died from unknown causes and 21 were parasitized by the wasp Perilitus coccinellae. The sex ratio of the surviving ladybirds was 68 females to 43 males, which was significantly different from unity $\left(\chi^{2}=5.6, p<0.05\right)$. The female 7 spot ladybirds were on average heavier than the males $(43.7$ $\mathrm{mg}$ vs $36.7 \mathrm{mg}$ on day $8,48.8 \mathrm{mg}$ vs $36.0 \mathrm{mg}$ on day 15 and $49.1 \mathrm{mg}$ vs $35.5 \mathrm{mg}$ on day $22\left(\mathrm{~F}_{1,109}>40, \mathrm{p}<0.001\right.$ in all cases)), therefore this sex ratio bias could have been caused by differential mortality of (lighter) males (Brakefield 1985b). Females also produced on average more fluid than males (5.0 $\mathrm{mg}$ vs $3.9 \mathrm{mg}$ on day $8,3.6 \mathrm{mg}$ vs $2.8 \mathrm{mg}$ on day 15 and 3.3 $\mathrm{mg}$ vs $2.6 \mathrm{mg}$ on day $22\left(\mathrm{~F}_{1,109}>8.5, \mathrm{p}<0.004\right.$ in all cases $\left.)\right)$.

Although females produced $28 \%$ more defence fluid than males, because the body weight also varied between the sexes the amount of fluid produced as a proportion of (prebleeding) body weight was more constant. The mean amounts of reflex blood produced as a proportion of body weight for males and females on days 8,15 and 22 were $0.106 \pm 0.0037$ vs $0.115 \pm 0.004, \quad 0.077 \pm 0.0039$ vs $0.074 \pm 0.0026$ and $0.074 \pm 0.0032$ vs $0.066 \pm 0.0027$, respectively. Analysis of variance revealed no statistically significant differences between any pair of values and all analyses were carried out on angular transformed data. The maximum proportion produced by a male at one time was 0.151 and by a female 0.237 . As shown above, there were no differences between the male and female data and, in addition, the distributions about the means were normal for fluid as a proportion of body weight for days 8,15 and 22 . Therefore, the mean of the three values from days 8,15 and 22 for each beetle were taken and the sexes combined to illustrate the normality of the distribution of the amount of fluid produced as a proportion of body weight (Fig. 2).

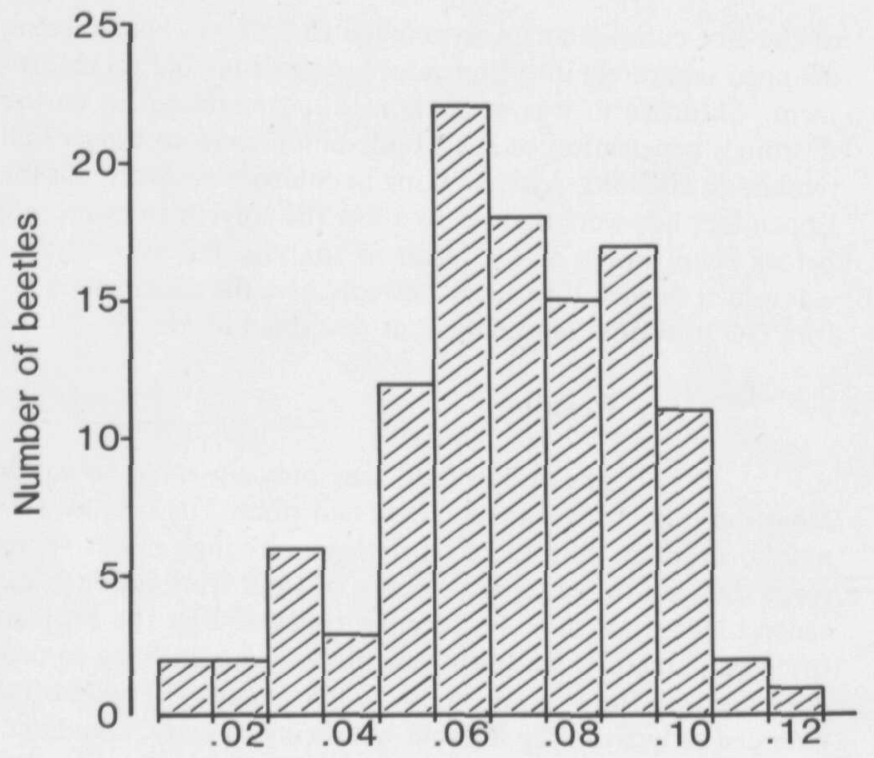

Fluid weight/body weight

Fig. 2 Distribution of means of the three amounts of fluid produced by each beetle on days 8,15 and 22 as a proportion of fresh body weight

The amount of coccinelline $(\mu \mathrm{g})$ per $\mathrm{mg}$ reflex fluid for males and females on day 8 was $6.4 \pm 0.4$ and $7.1 \pm 0.4$ (not significantly different, n.s.), respectively. However, the subsequent bleedings on days 15 and 22 produced mean concentrations $(\mu \mathrm{g} / \mathrm{mg}$ ) of $2.7 \pm 0.2$ and $2.5 \pm 0.3$ (n.s.) for males and $4.4 \pm 0.4$ and $5.3 \pm 0.4$ (n.s.) for females, indicating a higher alkaloid concentration in reflex fluid produced by females (day 15: $\mathrm{t}=2.965, \mathrm{p}<0.01$; day 22: $\mathrm{t}=4.49$, $\mathrm{p}<0.001)$.

An analysis was carried out to determine whether the amount of reflex blood produced varied between beetles in a consistent manner, i.e. whether some beetles tended to produce more than the overall mean and others less. The amount of reflex fluid produced was always significantly and positively correlated with fresh body weight. Therefore the weight of reflex fluid was corrected for body weight by taking residuals about the regression line of weight of fluid on body weight. Separate sets of residuals were obtained for males and females on days 8,15 and 22 . Analyses of variance were carried out separately on the male and female sets of residuals. The residuals varied significantly between beetles for both sexes (female: $F_{2,67}=3.62, p<0.001$; male: $F_{2,42}=4.46$, $\mathrm{p}<0.001$ ). Plots of fluid residuals from day 15 on day 22 are shown in Figure 3 to illustrate the consistency in the amount of fluid produced by individual beetles through time.

Similar analyses were carried out using coccinelline concentration corrected for amount of fluid produced and fresh body weight. The analysis of variance revealed no significant among beetle variation for females $\left(F_{2,67}=1.24\right.$, n.s.), whereas males did vary significantly $\left(F_{2,42}=2.08\right.$, $\mathrm{p}<0.002)$. Weight of fluid residuals and coccinelline concentration residuals were not significantly correlated with each other. 


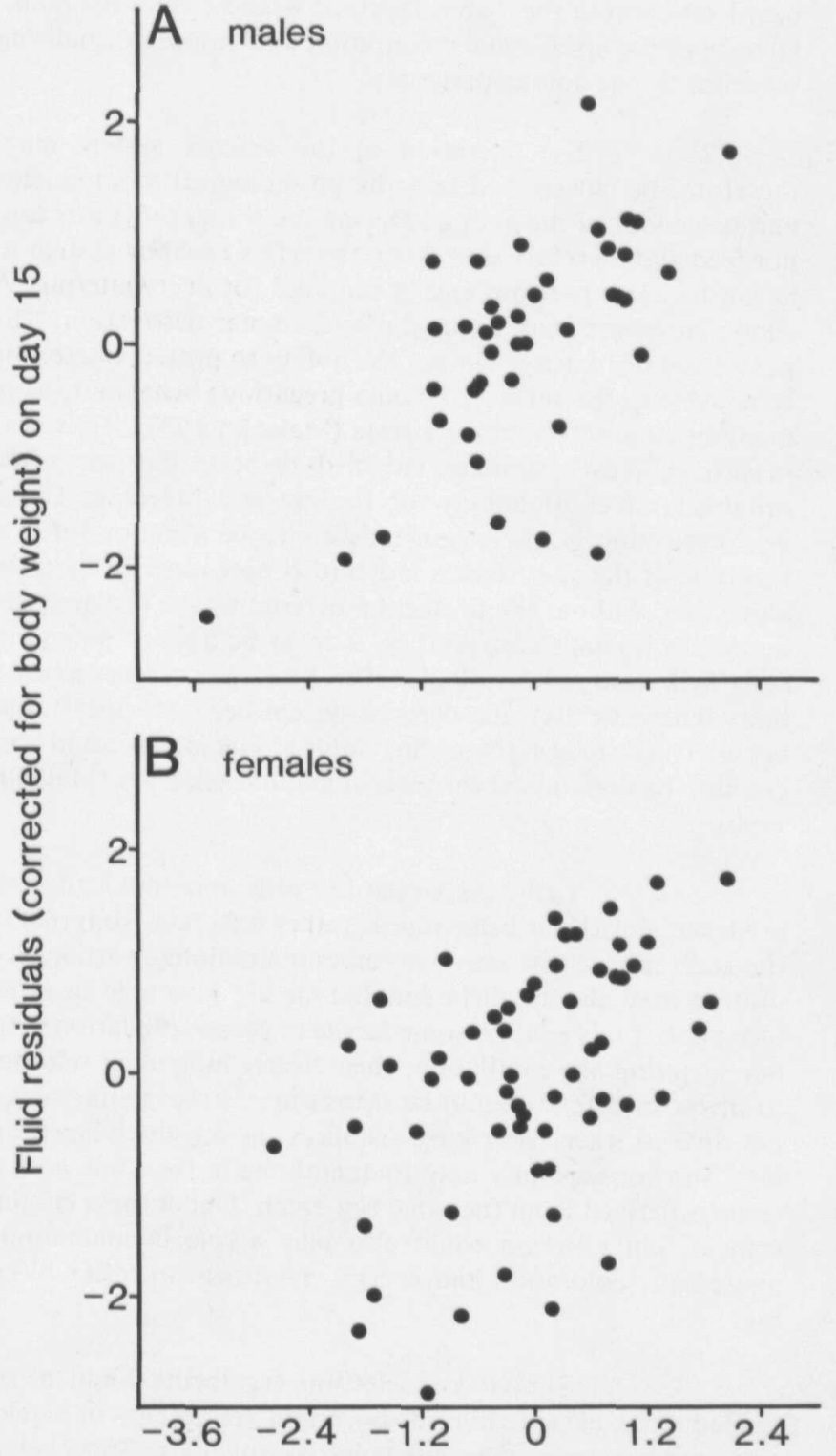

Fluid residuals on day 22

Fig. 3 Plots of residuals from regression lines of fluid produced on fresh body weight from day 15 on the same residuals from day 22 for males $(\mathrm{A})$ and females $(\mathrm{B})$ (correlation coefficients $=0.65$ and 0.53 respectively, $p<0.001$ for both)

No effect of number of eggs produced on either the amount of fluid produced or the amount of coccinelline therein was detected. Some of the ladybirds parasitised by. $P$. coccinellae produced remarkably large quantities of reflex fluid prior to immobilization by the parasite (more than $20 \%$ of fresh body weight). This effect could have been produced by the parasite having caused widespread internal damage. However, since the variation in the amount produced was high and the sample size quite small, the mean quantity of fluid produced by parasitised ladybirds did not differ significantly from that produced by healthy animals.

\section{Discussion}

The technique described here for the collection of the defence fluid is simple and yet enabled the collection of almost all of the material exuded, resulting in very little surface contamination of the beetles (Table 1). This makes possible the accurate measurement of the amount of fluid produced and the amount of alkaloid therein. Furthermore, a large proportion of the total body alkaloid could be collected (over $70 \%$ in group $\mathrm{C}$ animals). As well as the description of variation at the phenotypic level, it also becomes possible to estimate components of genetic variance using quantitative genetic techniques (Becker 1967; Falconer 1981). Questions can then be asked concerning the way in which evolution has influenced the development of the defence system by measuring additive genetic variances and covariances, and integrating the energetically costly (up to $24 \%$ of fresh body weight) process of defence fluid production into a life history framework.

The fluid was only seen to exude from the ti$\mathrm{bia} / \mathrm{femur}$ joint of all six legs. This has not only been noted by, for example, Hodek (1973) and Majerus \& Kearns (1989) in 7-spot ladybirds, but also in other beetles, such as the related coccinellid, the Mexican bean beetle, Epilachna varivestis (Eisner et al. 1986).

The results of the study indicated that coccinelline was not only present in the defence fluid, but also generally distributed throughout the body. It is possible that coccinelline is contained only within the haemolymph. However, it was notable that the coccinelline concentrations of the legs and wings (plus elytra) were similar to those of the thorax and abdomen (Table 1), even though the former contain rather little haemolymph. Such a comparatively uniform distribution may involve the production of defence fluid during the larval stages since larvae produce defence fluid from dorsal glands (pers. obs.). As a larvae pupates, the body contents (apart from the imaginal disks) become fluid and, providing that coccinelline is not metabolised in some way, the alkaloid may become dispersed throughout the pupa. As the imago develops within the pupal case, coccinelline could become integrated into the body of the ladybirds as well as carried in the reflex fluid. A 7-spot ladybird is therefore always distasteful to predators, irrespective of whether it has just reflex bled or not.

Kay et al. (1969) found no blood cells in the defence fluid of $C$. septempunctata, although, as we noted, the colour of the fluid exuded was always the same as the colour of the haemolymph (as seen through the throat membrane). If the fluid that carries the coccinelline is derived from the haemolymph (as implied by its colour), it is possible that the haemolymph is filtered prior to use for defensive purposes. Several observations suggested that adult ladybirds contain structures within the body that are concerned primarily with the production and activation of the defence system. Firstly, the coccinelline concentration of the reflex blood was always much higher (at least 10 times) than the rest of the body. Also, the amount of fluid produced as a proportion of the fresh body weight was often remarkably high; up to $23.7 \%$ ! This must represent a very high proportion of the total body fluid. Finally and perhaps most convincing, was the way in which fluid was released through each leg. It was quite straight forward to stimulate a ladybird to produce defence 
fluid from one leg (also noted by Eisner et al. 1986) until the supply became exhausted (as indicated by the change in fluid quality). If a second leg was then stimulated reflex blood was produced anew with the initial rich colour, which it could no longer do if it relied on body pressure to force the material out. The above observations are consistent with the existence of perhaps large, sack-like structures at the base of each leg into which reflex fluid is secreted or filtered specifically intended for the transport and utilization of the defensive alkaloid.

The results also suggest that the filling of these hypothetical sacks and the synthesis of coccinelline occurs independently. The alkaloid concentration of the defence fluid produced by group D animals on days 15 and 22 was much lower than that produced on day 8 , since the decrease in fluid production was less than the reduction in alkaloid production (Fig. 1). The alkaloid concentration dropped significantly more in males than in females $(41 \%$ and $68 \%$ of day 8 values, respectively). It is unclear why this should be but it also occurs in the 2-spot ladybird, Adalia bipunctata L. (de Jong et al. 1991). The inability of the ladybirds to attain the alkaloid concentration measured on days 15 and 22 after one week of feeding suggest that coccinelline can only be produced slowly, relative to the rate of fluid production. It may be that one or more steps in the biochemical pathway towards the synthesis of coccinelline is particularly rate limiting. However, an alternative explanation is that the coccinelline produced during feeding prior to day 8 was combined with alkaloid produced during the previous autumn, thus producing a superconcentrated 'reminder' for predators active early in the spring when ladybirds reappear from winter hibernation.

The ladybirds examined directly after winter hibernation (group A) produced very little defence fluid. It is likely that the production of defence fluid and winter hibernation are both energetically expensive (Sibly \& Calow 1986). Therefore, physiological flexibility to enable a hibernating ladybird to resorb and metabolise fluid produced during the previous autumn would seem to be a selectively advantageous option. During resorption (if it occurs) the coccinelline could remain behind in glands or the hypothesised sacks and consequently become very concentrated. This would account for the production of very little, but highly concentrated defence fluid by ladybirds in group A (and to a lesser extent group B). The consequence of such a strategy would be that an overwintering ladybird, or a ladybird having just emerged from hibernation, may not be able to produce defence fluid and thus defend itself directly, but is still packed with distasteful alkaloid.

In order for a predator, such as a bird, to experience the effects of coccinelline, an overwintering ladybird may have to be mutilated or even killed. However, winter and early spring ladybirds are often found together in hibernating groups (Hemptinne 1988; Majerus \& Kearns 1989) or feeding gregariously on early spring aphids (as were the ladybirds collected for the current study). These conditions appear to provide an ideal opportunity for operation of 'Green Beard' selection (Dawkins 1978; Guilford 1988; Malcolm 1990). The green beard trait would be the red/black aposematic colouration. Individuals possessing such a phenotype in a distasteful species could benefit from the possible death of an unrelated individual during the education of a naive predator. Green beard selection in the 7-spot ladybird would ensure the maintenance of the aposematic colouration and induce normalising selection on the colour pattern.

The operation of the defence system may, therefore, be closely tied into the physiological requirements and behaviour of the animal. During the winter ladybirds cannot feed and therefore shut down the reflex bleeding system so as not to waste precious energy required for overwintering. A similar response may occur during summer aestivation. The possession of toxicity, but not the ability to protect oneself by bringing it to the surface, favours gregarious behaviour, as in many other similarly toxic insects (Malcolm 1990). However, in spring and early summer, ladybirds disperse in order to find suitable sources of aphids for feeding and breeding. Green beard selection is, therefore, unlikely to be a major force at this time of the year since a ladybird is now more likely to be alone and, without the protection offered by the proximity of numerous noxious conspecifics, it must be able to defend itself. With food now available reflex bleeding becomes a possibility (energetically), the defence system becomes operational again. Thus, foraging/breeding adult aposematism could conceivably be maintained through individual selection (Malcolm 1990).

Ladybird larvae are also aposematically colored, but since their behaviour is rather different from that of the adult insects, the selective forces maintaining warning coloration may also be different. Larvae are also able to reflex bleed and if this enables some larvae to escape predation without suffering any mutilation, then clearly individual selection to invest in defence could be operating. However, larvae are not able to travel very long distances, as are the winged adults, and consequently may frequently be in the same area as siblings derived from the same egg batch. Under these circumstances, kin selection could also play a role in maintaining aposematic coloration and energy investment in reflex bleeding.

Similar kin selection arguments could be extended to the eggs. Ladybirds lay bright yellow eggs in batches and, consequently, they are quite conspicuous. The eggs of 7-spot ladybirds contain alkaloids (Pasteels et al. 1974). A predator finding an egg batch may destroy one or a few eggs, but the experience of the taste of the coccinelline may ensure the survival of the remaining eggs. Since the eggs in a single batch are all siblings, the aposematic yellow coloration of the eggs could quite clearly be maintained through kin selection.

The second goal of the experiment was to establish whether variation among beetles existed in the defence system, in contrast with the rather invariable general aposematic colour scheme. Davidson et al. (1989) quantified the amount of self-synthesised defensive carboxylic acid contained within the defence fluid of the carabid, Pasimachus subsulcatus and reported little variation between the beetles. However, their sample size was not very large. De Jong et al. (1991) found substantial individual variation in the defence system of 2-spot ladybirds. There are at least two ways in which variation could be maintained in the defence system of aposematically colored ladybirds: either automimicry, where some animals make little or no investment in defence and rely on protection through their distasteful and similarly colored conspecifics or variation maintained as a result of life history 
constraints (Rose \& Charlesworth 1981; Soliman 1982; Luckinbill et al. 1984; Bell \& Koufopanou 1986; Møller et al. 1989; Holloway et al. 1990a, b ). The first possibility would generate results consistent with a polymorphism or mixed ESS, i.e. a few fairly discrete categories of animals. Life history constraints may result in the existence of quantitative genetic variation maintained through the operation of pleiotropic gene action (Simmons et al. 1980; Rose 1982) and the consequent negative genetic correlations between energy-demanding life history characters.

The only ladybirds in group D not to produce defence fluid on day 8 were those that subsequently died and were therefore probably unhealthy to start with. Only one other ladybird (in group A) failed to reflex bleed, but it could have been unhealthy or not yet fed sufficiently after hibernation to have produced anything. The distributions of the amounts of fluid and coccinelline produced by the healthy ladybirds were not polymodal (see Fig. 2). There was, therefore, no evidence to support the operation of automimicry leading to discrete distributions of defended and undefended individuals.

The analysis, however, did reveal substantial variation among beetles for both the amount of fluid produced (males and females, see Fig. 2) and the coccinelline concentration of the fluid (males only). It is acknowledged that since we examined phenotypic variation this does not necessarily provide evidence of underlying genetic variation (Bell \& Koufopanou 1986). The fact that some beetles consistently produced more fluid than expected, and others less, may have been due to genes or to maternally inherited factors, or simply due to past experiences (perhaps conditions experienced during the larval stage). For whatever reason, the amount of fluid and coccinelline produced by each beetle was influenced by internal factors. However, in order to determine whether this phenotypic variation is the consequence of life history constraints, experiments need to be carried out to produce direct estimates of additive genetic variances and covariances. The experimental procedures described here provide the means to carry out such a study.

\section{Acknowledgements}

We are grateful to Dr N. M. Marples and three anonymous referees for their critical reading of the manuscript and suggestions for improvements. We also thank Dr. J. M. Pasteels and his colleagues for their advice and assistance during the early stages of this work. P. W. de Jong was supported by the Foundation for Biological Research (BION, grant number 436.031), which is subsidized by the Netherlands Organization for Scientific Research (NWO).

\section{References}

Ayer WA, Browne LM (1977) The ladybug alkaloids including synthesis and biosynthesis. Heterocycles 7:685-707

Becker WA (1967) Manual of Quantitative Genetics (3rd ed). Washington: Washington State University

Bell G, Koufopanou V (1986) The cost of reproduction. Pp 83-131 in Dawkins R \& Ridley M (eds) Oxford Surveys in Evolutionary Biology, Vol 3. New York: Oxford University Press

Brakefield PM (1985a) Polymorphic Müllerian mimicry and interactions with thermal melanism in ladybirds and a soldier beetle: a hypothesis. Biol J Linn Soc 26:243-267
Brakefield PM (1985b) Differential winter mortality and seasonal selection in the polymorphic ladybird Adalia bipunctata (L.) in the Netherlands. Biol J Linn Soc 24:189-206

Brower LP (1984) Chemical defence in butterflies. Pp 109-132 in VaneWright RI \& Ackery PR (eds) The Biology of Butterflies. Symp R ent Soc No 11. London: Academic Press

Brower LP, Brower JVZ, Corvino JM (1967) Plant poisons in a terrestrial food chain. Proc Natl Acad Sci 57:893-898

Brower LP, Pough FH, Meck HR (1970) Theoretical investigations of automimicry. I. Single trial learning. Proc Natl Acad Sci USA 66: 10591066

Cuenot L (1896) Sur la saignée réflexe et les moyens de défense de quelques insectes. Archs Zool exp gén 4:655-680

Davidson BS, Eisner T, Witz B, Meiwald J (1989) Defensive secretions of the carabid beetle Pasimachus subsulcatus. J Chem Ecol 15:16891697

Dawkins R (1978) The Selfish Gene. London: Granada Publishing

Dobzhansky Th, Sivertzev-Dobzhansky NP (1927) Die geographische Variabilităt von Coccinella septempunctata $\mathrm{L}$. Biol Zentrallblatt 47:556569

Eisner T, Goetz M, Aneshansley D, Ferstandig-Arnold G, Meinwald J (1986) Defensive alkaloid in blood of Mexican bean beetle (Epilachna varivestis). Experientia 42:204-207

Falconer DS (1981) Introduction to Quantitative Genetics (2nd ed). London: Longman

Fisher RA (1930) The Genetical Theory of Natural selection. Oxford: Oxford University Press

Frazer JFD, Rothschild M (1960) Defence mechanisms in warningly coloured moths and other insects. Proc 11th int Congr Ent Symp 4:249256

Gibson DO (1974) Batesian mimicry without distastefulness. Nature 250: $77-79$

Guilford T (1988) The evolution of conspicuous coloration. Amer Nat Suppl. 131:S7-S21

Guilford T, Nicol C, Rothschild M, Moore BP (1987) The biological roles of pyrazines: evidence for a warning odour function. Biol J Linn Soc 31:113-128

Happ GM, Eisner T (1961) Hemorrhage in a coccinellid beetle and its repellent effect on ants. Science 134:329-331

Hemptinne JL (1988) Ecological requirements for hibernating Propylea quatuordecimpuntata (L.) and Coccinella septempunctata (Col: Coccinellidae). Entomophaga 33:505-515

Hodek I (1973) Biology of Coccinellidae. Prague: The Hague and Academia

Hollande CH (1911) L'autohémorrhée ou le rejet du sang chez les insectes (toxicologie du sang). Archs Anat microsc 13:171-318

Holloway GJ, Povey SR, Sibly RM (1990a) The effect of new environment on adapted genetic architecture. Heredity $64: 323-330$

Holloway GJ, Sibly RM, Povey SR (1990b) Evolution in toxin stressed environments. Funct Ecol 4:289-294

de Jong PW, Holloway GJ, Brakefield PM, de Vos H (1991) Chemical defence in ladybird beetles (Coccinellidae). II. Amount of reflex fluid, the alkaloid adaline and individual variation in defence in 2-spot ladybirds (Adalia bipunctata). Chemoecology 2:15-19

Kay D, Rothschild M, Aplin R (1969) Particles present in the haemolymph and defensive secretions of insects. J Cell Sci 4:369-379

Luckinbill LS, Arking R, Clare MJ, Cirocco WC, Buck SA (1984) Selection for delayed senescence in Drosophila melanogaster. Evolution 38:996-1003

Majerus M, Kearns P (1989) Ladybirds. Naturalist Handbooks 10. Slough, England: Richmond Publishing Co Ltd

Malcolm SB (1990) Mimicry: status of a classical evolutionary paradigm. TREE 5:57-62

Malcolm SB, Brower LP (1989) Evolutionary and ecological implications of cardenolide sequestration in the monarch butterfly. Experientia $45: 284-295$

Marples NM (1990) The influence of predation on ladybird colour pattern. $\mathrm{Ph} \mathrm{D}$ thesis: University of Wales College of Cardiff

Marples NM, Brakefield PM, Cowie RJ (1989) Differences between the 7-spot and 2-spot ladybird beetles (Coccinellidae) in their toxic effects on a bird predator. Ecol Entomol 14:79-84

Maynard-Smith J (1982) Evolution and the Theory of Games. Cambridge: Cambridge University Press

Meuller RH, Thompson ME, DiPardo RM (1984) Stereo- and regioselective total synthesis of the hydropyrido [2, 1, 6-de]quinolizine ladybug defensive alkaloids, J Org Chem 49:2217-2231

Møller H, Smith RH, Sibly RM (1989) Evolutionary demography of a bruchid beetle. I. Quantitative genetic analysis of the female life history. Funct Ecol 3:673-681

Pasteels JM, Deroe C, Tursch B, Braekman JC, Daloze D, Hootele C 
(1973) Distribution et activites des alcaloides defensifs des Coccinellidae. J Insect Physiol 19:1771-1784

Pough FH, Brower LP, Meck HR, Kessell SR (1973) Theoretical investigations of automimicry: multiple trial learning and the palatability spectrum. Proc Natl Acad Sci 70:2261-2265

Rose MR (1982) Antagonistic pleiotropy, dominance, and genetic variation. Heredity 48:63-78

Rose MR, Charlesworth B (1981) Genetics of life history in Drosophila melanogaster. I. Sib analysis of adult females. Genetics 97:173-186

Rothschild M (1961) Defensive odours and Mullerian mimicry among insects. Trans R Soc Lond 113:101-121

Rothschild M (1985) British aposematic Lepidoptera. Pp 9-62 in Heath J (ed) The Moths and Butterflies of Great Britain and Ireland, Vol. 2. Cossidae to Helionidae. Colchester, England: Harley Books

Sheppard PM, Turner JRG, Brown KS, Benson WW, Singer MC (1985) Genetics and the evolution of Mullerian mimicry in Heliconius butterflies. Phil Trans Roy Soc Lond 308:433-613

Sibly RM, Calow P (1986) Physiological Ecology of Animals: An Evolutionary Approach. Oxford: Blackwell

Simmons MJ, Preston CR, Engels WR (1980) Pleiotropic effects on fitness of mutations affecting viability in Drosophila melanogaster. Genetics $94: 467-475$
Smith RH, Sibly RM, Møller H (1987) Control of size and fecundity in Pieris rapae: towards a theory of butterfly life cycles. J Anim Ecol 56:341-350

Soliman MH (1982) Directional and stabilizing selection for development time and correlated response in reproductive fitness in Tribolium $c a-$ staneum. Theoret Appl Gen 63:111-116

Turner JRG (1977) Butterfly mimicry: the genetical evolution of an adaptation. Evol Biol 10:163-206

Turner JRG (1984) Mimicry: the unpalatability spectrum and its consequences. Pp 141-165 in Vane-Wright RI \& Ackery PR (eds) The Biology of Butterflies. Symp R Ent Soc No 11. London: Academic Press

Tursch B, Daloze D, Dupont M, Hootele C, Kaisin M, Pasteels JM, Zimmermann D (1971) Coccinellin, the defensive alkaloid of the beetle Coccinella septempunctata. Chemia 25:307

Tursch B, Daloze D, Braekman JC, Hootele C, Pasteels JM (1975) Chemical ecology of arthropods - X. The structure of myrrhine and the biosynthesis of coccinelline. Tetrahedron 31:1541-1543

Tursch B, Braekman JC, Daloze D (1976) Arthropod alkaloids. Experientia 32:401-407

Williams GC (1966) Natural selection, the costs of reproduction and a refinement of Lack's principle. Amer Nat 100:687-690 